\title{
POSITIVE INFLUENCING FACTORS OF COMMERCIAL PROPERTY DEVELOPMENT: CASE OF LITHUANIA
}

\author{
Valery KOMISAROV ${ }^{1}$, Linda KAUŠKALE ${ }^{2}$, Natalija LEPKOVA ${ }^{3}$ \\ ${ }^{1,2}$ Riga Technical University, Latvia \\ ${ }^{3}$ Vilnius Gediminas Technical University, Lithuania \\ Corresponding author e-mail: Linda.Kauskale@rtu.lv
}

\begin{abstract}
Presently the conditions for the commercial property development in Lithuania are favourable. The market indicators are demonstrating positive tendencies. Many international companies are entering the Lithuanian markets because of the supportive governmental instruments of competitive policy for these international companies. There is high demand for the commercial premises, and the respective governmental authorities are regularly improving the construction procedures. These are the factors, which are affecting the commercial property development activities in Lithuania. The aim of this paper is to highlight the factors, which are positively affecting the commercial property development in Lithuania. The key market indicators, supportive instruments for international companies and improvements of the construction procedures in Lithuania are reviewed by the authors, with prime focus on the capital of Lithuania - Vilnius. This paper is intended as guidance to the developers, who are entering the Lithuanian commercial property market.
\end{abstract}

Keywords: Commercial property development in Lithuania, construction procedures, governmental supportive instruments, investments.

\section{INTRODUCTION}

One of the most important preliminary phases of project development is market analysis. It provides guidance to many decision makers, who are involved in property development. This ongoing process provides information during the pre-development, acquisition, development, marketing, and disposition of property.

The objective of market analysis is to minimize the risks and maximize the opportunities for the developer by providing the analysis that is as timely and accurate as possible.

Market analysis is used by the project developer to determine, whether the location is suitable for the development, and which products are best meeting the demands of the market (Brett \& Schmitz, 2005). Market analysis takes into consideration many factors, such as demand and supply level, vacancy rates and characteristics of vacant stock, recent absorption of space, projects under construction and proposed projects, market rents or sales prices, market factors, which are affecting the property, legal considerations, market strengths (Brett \& Schmitz, 2005; Wofford \& Clauretie, 1992). 
International developer may perform market analysis when entering a new foreign market and developing the market entry strategy. Globalization brings huge implications and offers potentials to the new world economies and to the new markets.

Market entry strategy is used to make the new foreign market entry beneficial for the business expansion in terms of services, products, technology, human and other resources. It requires the company to decide which market to enter (decision on the market selection), how to enter (decision on the entry method), and when to enter (decision on the entry timing). Hence, focusing on the market selection decision is one of the important factors in the process of internationalization and is crucial in order to ease the complexity and difficulty of global market expansion.

Several important factors are influencing the market entry, such as market competition, country market potential, economic, social and political environment, government's rules and regulations (Maznah Mat, Mohd Saman, \& Rahidad Mohd, 2014). The authors give a brief review of these factors in Lithuania.

Toivonen and Viitanen (2016) underlined that commercial property market is closely linked to the surrounding society as commercial buildings have several economic, environmental, political, social and cultural influences. Toivonen and Viitanen (2015) also analysed the forces of shaping of future commercial property market. Many important indicators, such as demand, supply, vacancy rates, absorption volume, proposed projects, as well as economic indicators and legal and tax matters are being included in the regular property market overviews of the leading property companies (like "CBRE", "Colliers International", "Newsec"). These overviews are useful for understanding of many property markets, including the Lithuanian market (Colliers International, 2016).

The data collection on the demands and prevailing market trends are significant in construction and property development industries. Proper market research may help to understand the market needs (Alhammadi, Algahtany, Kashiwagi, \& Sullivan, 2016).

The main commercial property market indicators, benefits for international companies, development of the construction procedures in Lithuania are reviewed in further sections of this paper. All these factors are significant for local Lithuanian developers as well as for international companies, international construction companies and international developers, which are entering the Lithuanian market.

\section{OVERVIEW OF COMMERCIAL REAL ESTATE MARKET}

There are number of factors and stages of the development process that should be considered by the property developer. The factors are including such issues as economy, property cycles and markets, government policy and strategy, legislation, as well as environment, population, politics, transport, technology, etc. 
All these factors can significantly affect the viability of progress of the development project, thus ultimately affecting profitability.

There are several different illustrations of the property development process. One of them consists of four principal stages and contains fourteen core activities, which are illustrated in Fig. 1. One or all of these activities is subject to change and variation depending on the nature of the specific development and its various elements (Jowsey, 2015).

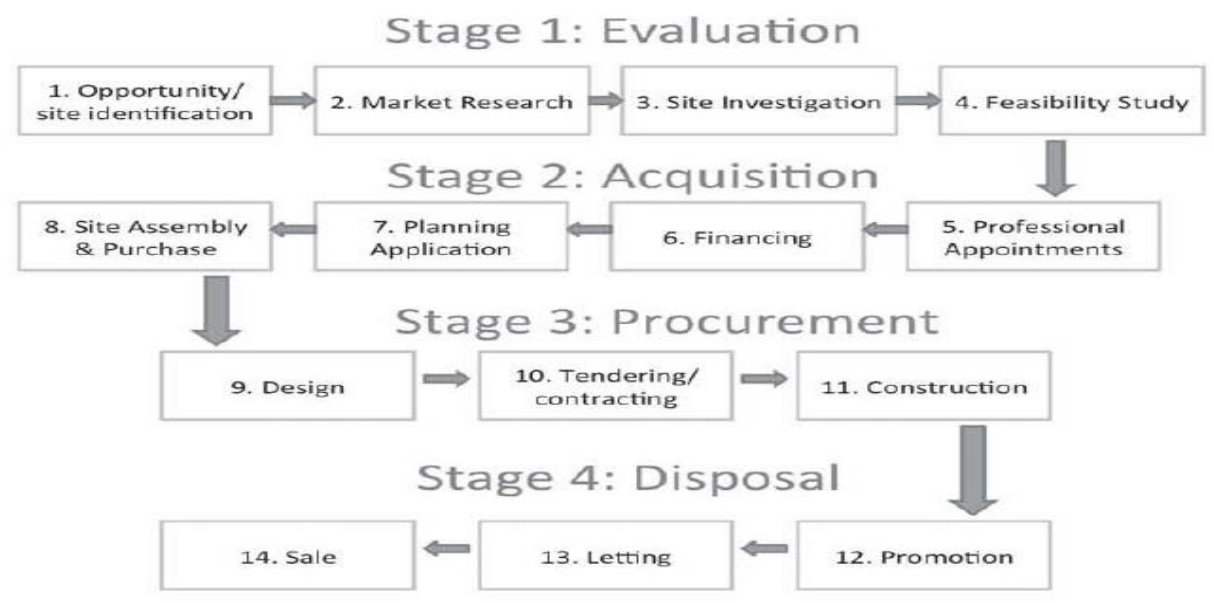

Fig. 1. 14 phases of property development (Jowsey, 2015, p. 122).

Fig. 1 shows the importance of the market research. It is one of the important preliminary phases of each project, as it was mentioned above.

Taking into consideration the importance of the market research and country's economic indicators, the authors review the opinions of the leading property companies on Lithuanian commercial property market, as well as economic indicators, expressed in the "World Economic Forum".

Referring to "Baltic Property Market Report 2015", prepared by the property company "Newsec", "Lithuania's property market has finally stabilized after several volatile years (in 2014). Growing demand has encouraged developers to start new commercial and residential projects. Improvement in retail turnovers stimulated the development of logistics and retail projects, furthermore, activity on previously frozen projects resumed. Healthy GDP growth levels, coupled with decreasing unemployment, are likely to lead to higher consumption and demand, lower vacancy rates and higher rents on the property" (Newsec, 2015). The highest investment volumes in the Baltic States in 2015 were observed in retail sector. The investment volumes per sector in the Baltic States are shown in Fig. 2.

Commercial real estate market trends in Vilnius are positive. Vilnius was nominated as the "most dynamically developing city 2016" at the $4^{\text {th }}$ annual CEE Shared Services and Outsourcing Awards (BiznesPolska, 2016). One of the reasons was the presence of several international companies in Vilnius, for example, global technology and business support competence centre of "Nasdaq", technology centre of "Barclays", cloud-based web development platform "Wix", 
the world leader in life science research "Thermo Fisher Scientific" and others. All these companies create demand for commercial properties. For example, "Thermo Fisher Scientific" has invested 13 million US dollars in mix-used building (for research, development, manufacturing, warehousing and other purposes) (Thermo Fisher Scientific, 2012; Invest Lithuania, 2016). Due to the high level of demand, there is a favourable situation in Lithuania for the development of large projects. For instance, the lease agreement between the international developers "VASTINT" and "IT service centre of Danske Bank" was signed on May 2015. The lease object was an office building in Vilnius with total area of $55000 \mathrm{~m}^{2}$. It was one of the largest transactions in the Lithuanian office market (Vastint, 2016).

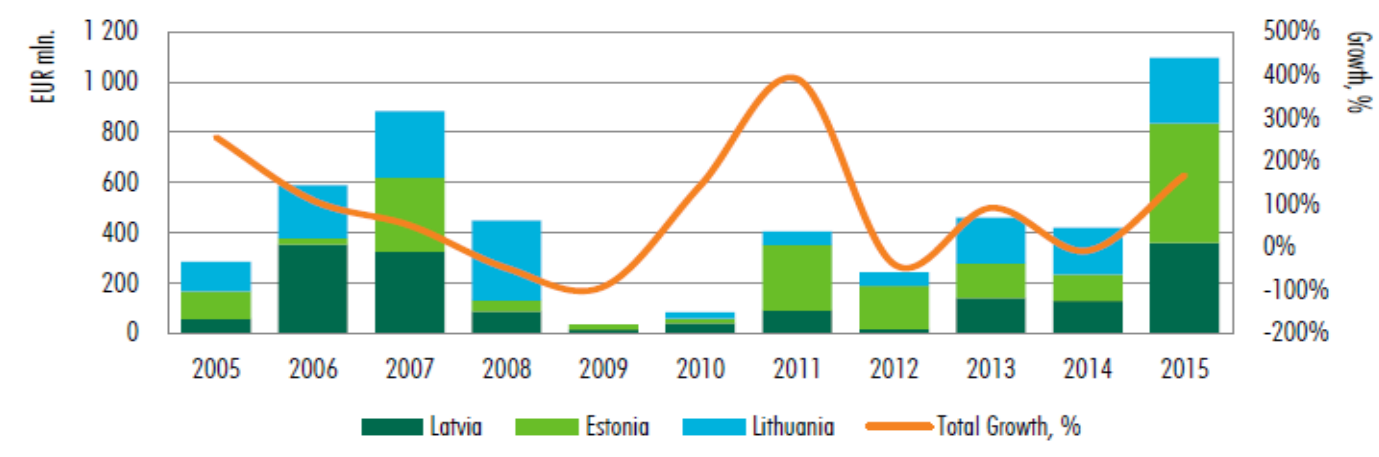

Fig. 2. Investment volumes by sectors per country, 2015 (CBRE, 2016, p. 2).

Economic indicators are also important for commercial real estate analysis. In many cases they are directly affecting the property market development and decision making process. Factors, which are affecting the economy and property market ranking indicators in the Baltic States, are shown in Table 1.

Table 1 also helps to identify the economic factors positively affecting commercial real estate market. In the case of Lithuania, commercial real estate market indicators are positively influenced by such economic factors as strength of protection of investors, transport infrastructure evaluation and other factors, including general global competitiveness index that is higher than the median value of all 140 analysed countries. The authors have compared the key indicators of the Lithuanian commercial property market during the last years -2014 and 2015 (Table 2). Three most demanded categories of prime commercial property were analysed - office buildings, retail projects, industrial projects. 
Table 1. Factors, which are affecting the economy and property market ranking indicators in the Baltic States. Data source: World Economic Forum, 2016, table made by authors

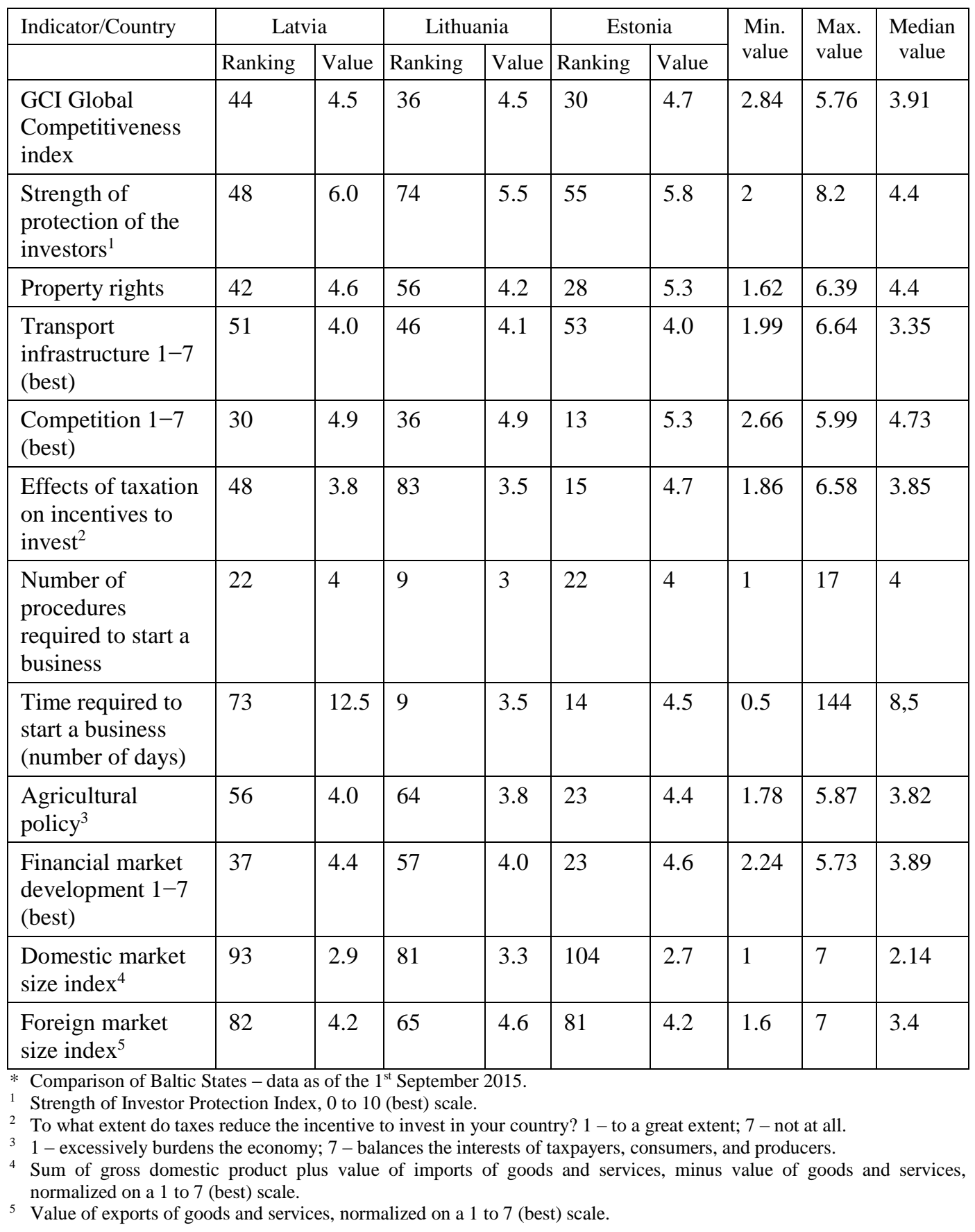

Indicators, which are included in Table 1 and Table 2, show the improvement of economic and investment climate in 2014. As a result, rent rates and yield rates rose. The development activities in 2014 and 2015 were on a similar level.

The positive investment climate in 2014 contributed to the increase in the investment volumes in 2015. However, taking into consideration the occurrence 
of many new projects, the vacancy rates rose for retail spaces and industrial spaces, and the growth of the rent rates slowed down.

It is being expected, that in 2016, Vilnius will remain a favourable location for investments, comparing with other Baltic capitals. Currently there is limited supply of prime assets in Lithuania. Retail and office assets will be in the highest demand with an attractive rate of return (CBRE, 2016, p. 5).

Table 2. Market indicators of Vilnius commercial property market in 2014 and 2015 (Colliers International, 2015, 2016, table made by authors)

\begin{tabular}{|l|l|l|}
\hline Indicator & Year 2014 & Year 2015 \\
\hline Office buildings under development (Vilnius) & 14 & 14 \\
\hline Retail projects under development (Vilnius) & 6 & 5 \\
\hline Industrial projects under development (Vilnius) & 3 & 4 \\
\hline & & \\
\hline Dynamics of rent rates (office spaces) & $+4 \%$ (p.a.) & $+2.8 \%$ (p.a.) \\
\hline Dynamics of rent rates (retail spaces) & $+8.5 \%$ (p.a.) & $+3.5 \%$ (p.a.) \\
\hline Dynamics of rent rates (industrial spaces) & $+3.5 \%$ (p.a.) & $+1.5 \%$ (p.a.) \\
\hline & & \\
\hline Dynamics of vacancy rates (office spaces) & $6.5 \%$ & $5 \%$ \\
\hline Dynamics of vacancy rates (retail spaces) & $1.9 \%$ & $2.5 \%$ \\
\hline Dynamics of vacancy rates (industrial spaces) & $2.2 \%$ & $3.8 \%$ \\
\hline Average yield & $7.5-9 \%$ & $7-8.75 \%$ \\
\hline $\begin{array}{l}\text { Annual investment volume (office, retail, } \\
\text { industrial), millions EUR }\end{array}$ & 298 & 444 \\
\hline
\end{tabular}

The problem could also occur for the capital reinvesting in case of successful asset sales. It can be a reasonable solution for the development of a prime class commercial property project in Lithuania due to lack of competitive projects and high level of demand (CBRE, 2016, p. 5).

\section{SUPPORTIVE INSTRUMENTS FOR INTERNATIONAL COMPANIES}

\subsection{Activities of the Investment Development Agency "Invest Lithuania"}

Government might play an important role by influencing the market entry decision of the companies and providing a strong support and promotion. (Maznah Mat, Mohd Saman, \& Rahidad Mohd, 2014).

In the authors' opinion, the governmental agency "Invest Lithuania" plays an important role in attracting the international firms and companies, which are entering the Lithuanian market.

"Invest Lithuania" helps global, export-oriented businesses to create highly skilled jobs in Lithuania. Agency's experts are able to bring their extensive experience to a number of business sectors, while particularly focusing on shared 
services, manufacturing, technology and life sciences. Lithuania stands out in the region with its strong services centres, games industry and information technologies.

The agency informs investors on business costs, labor, tax \& legal settings and other business areas. It connects the investors to its extensive partner network and organizes business meetings in Lithuania. It facilitates establishing and launching of the company, assists the investors in accessing the state financial support and provides a range of training schemes. It supports the investors in dealing with problems and advocates for more business friendly laws (Invest Lithuania, 2016a).

The volume of the attracted projects and investments (as a result of "Invest Lithuania" activities) has risen in 2015. Thirty-one new investment projects were brought to Lithuania, so 2015 was a record-breaking year for "Invest Lithuania".

Whilst the number of the attracted projects and created positions increased by $20 \%$ and $50 \%$ respectively, there was nearly a fivefold rise in the investment volume in 2015, from 30 million EUR in 2014 to 144 million EUR in 2015 (Invest Lithuania, 2016b).

The number of created new jobs is also important. The investment projects, which were attracted in 2015, will create at least 2647 new positions over the next three years. Around 1500 of these positions will be in shared services, whilst over 600 new positions will be created in the manufacturing sector.

Consequently, new-coming international companies provide good opportunities for the developers. It is reasonable to build premises for these companies - office buildings, industrial buildings, etc. For instance, two companies, which are supported by the "Invest Lithuania" (information technology company "Visma Lietuva" and telecommunication company "TEO LT") are tenants of the business centre "3 BURES" in Vilnius (Invest Lithuania, 2016b). Therefore, activity of the "Invest Lithuania" is beneficial for the investor, who owns this business center and who receives rental income from these tenants.

Additionally, in terms of capital, the largest investments announced in 2015 were the following: 50 million EUR construction project in Klaipeda Free Economic Zone by "Neo Group" and the construction of a new 34 million EUR production facility by "Eternit Baltic" (Invest Lithuania, 2016c).

Also it should be noted that the large amount of new positions is a positive trend for the residential market. Young and active employees may demand new apartments (for sale or lease).

Linda de Putāne, Head of LIAA's Investment Promotion Division, has also approved the importance of attracting international companies. She stated that Riga is being outpaced by Vilnius due to lack of high-quality office space. In addition, Vilnius is the most competitive capital in the Baltic States for big foreign investors. According to her, several global companies already have offices in Vilnius, which is the key advantage (Invest Lithuania, 2016d). 


\subsection{Special Economic Zones}

There are special zones established by the state, which ensure beneficial business conditions. These are seven free economic zones in Lithuania, located in the country's economic centres. There are beneficial conditions for business development, industrial sites with physical and/or legal infrastructure, support services, and tax incentives. Corporate profit tax of $0 \%$ is applied to the companies, which are operating in these zones, during the first 6 years of their operation (and only $7.5 \%$ tax over the next 10 years). There is no tax on dividends and no property tax (Invest Lithuania, 2014).

Besides the "seven free economic zones", there are five "science and technology valleys". These are integrated science, training and business centres where research, training and knowledge-based businesses are clustered in one location. Each of the five valleys is dedicated to specific competences and industries, with the aim of exchange and development of ideas with like-minded professionals.

Expenses incurred by the companies, which are engaged in research and development projects in Lithuania, are deducted from the taxable income three times (Invest Lithuania, 2016e).

From the perspective of the property developers, it is favourable to perform development in these "free economic zones" or "science and technology valleys". Due to tax deductions and other supportive instruments, these locations will be in demand for a long time (at least 16 years). The international companies, which are operating there, will create demand for the industrial and office premises. From the lease perspective, these companies are stable, professional, international and reliable potential lessees.

Moreover, "build-to-suit" projects can be performed in "free economic zones" or "science and technology valleys". The developer can offer construction of suitable premises for the companies, which are initiating business operations in these zones.

\section{IMPROVEMENT OF THE CONSTRUCTION PROCEDURES}

The improvement of the construction procedures includes the creation of an institutional environment that facilitates a competitive business environment for the efficient construction industry. It is important that the construction industry can stimulate the economic growth. It comes from the strong linkages between the construction and other sectors in the economy. The construction industry is one of the top four out of twenty economic sectors in terms of inter-sectoral linkages, backward and forward linkages.

Backward linkages include, for example, expansion of business of manufacturers of building materials and components (due to increase in the construction volumes). Forward linkages include, for example, rising of the employment level, because the construction industry is more labour intensive than many other industries.

Therefore, stimulation of the construction projects can be used as a tool for the government to stabilize or improve the economy (Giang \& Pheng, 2011). 
Regular improvement of the construction procedures is important. In order to improve state territorial planning and construction supervision, the Lithuanian State Territory Planning and Construction Supervision Departments of County Head Administrations have been merged with the Inspectorate, and one State Territorial Planning and Construction Inspectorate under the Ministry of Environment with the territorial divisions in counties has been established (hereinafter referred to as the Inspectorate).

One of the Inspectorate's priorities is "to become a construction participant's consultant and adviser rather than controlling and punishing institution". Also it "will be an innovative organization where motivated employees work together". The Inspectorate uses the following IT systems: INFOSTATYBA - information system of construction permits and state supervision of constructions of the Republic of Lithuania, TPDRIS - information system of preparation of the territorial planning documents and the state supervision of the process of territorial planning, TPDR - Register of Territorial Planning Documents of the Republic of Lithuania, RVIS - risk management information system (Nalivaikiene, 2015). These systems are going to be reviewed further in the paper.

In 2014, the Lithuanian municipalities electronically received $62 \%$ of applications for obtaining of the construction permits through the "Infostatyba" system. It largely overcomes the target of $47 \%$ for the same year set by the government. Formally introduced in November 2003, "Infostatyba" system started being operational several years later. The system is managed by the State Territorial Planning and Construction Inspectorate. "Infostatyba" works both as a front-desk and back-office. While managed centrally, it is operated mostly by the staff of individual municipalities and connects in real time all the public authorities that are to be involved in each permit application case (OECD, 2015, pp. 168-169, p. 173).

Additionally, the user of the "Infostatyba" system can be informed about the changes in the status of the submitted applications via mobile apps, e-mail or SMS (Nalivaikiene, 2015).

This system is considered to be international good practice and is particularly welcomed by stakeholders (OECD, 2015, pp. 168-169, p. 173).

The dynamics of electronical applications (related to construction processes) is shown in Fig. 3.

TPDRIS (information system of preparation of the territorial planning documents and the state supervision of the process of territorial planning) is a remote information system, which is available to natural and legal persons, for preparation of the territorial planning documents. It enables the authorities to perform centralized state supervision of the process of preparation of territorial planning documents.

This system allows preparing and correcting state-level complex territorial planning documents, municipal-level complex territorial planning documents, local-level complex territorial planning documents (general plans or detail plans), and special territorial planning documents. 


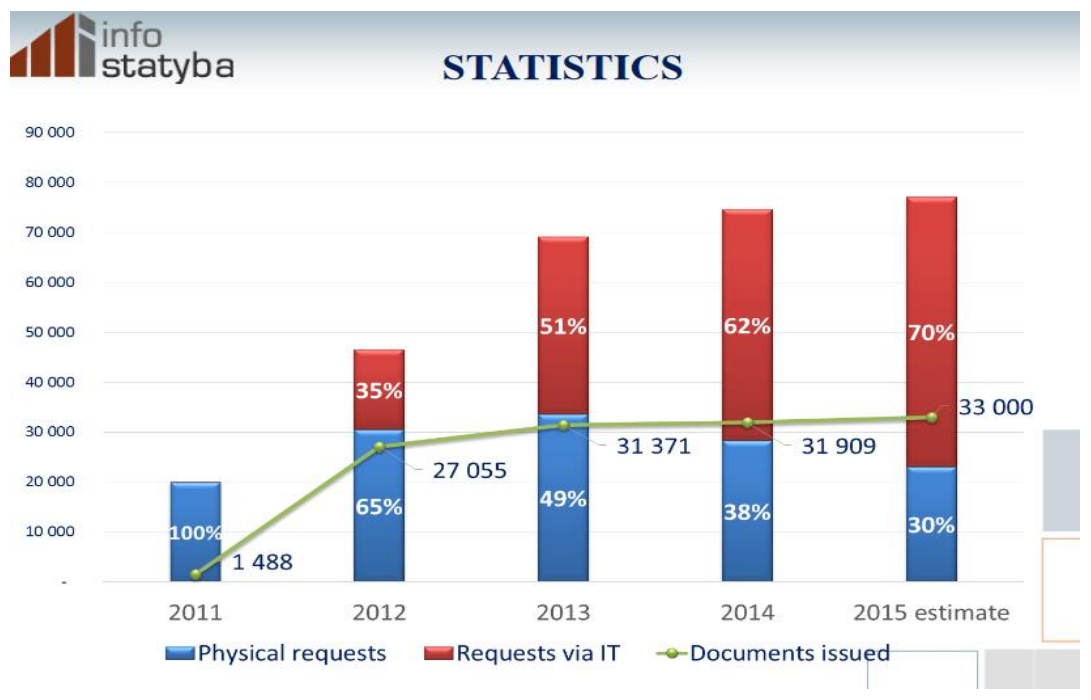

Fig. 3. The dynamics of electronical applications (related to construction processes) (Nalivaikiene, 2015).

There is graphical and descriptive information about the available property, as well as information from external data sources (Real Property Cadaster, Cultural Heritage Register, Forest Cadaster, State Protected Areas Register, etc.) available in TPDRIS.

Another system is TPDR - Register of Territorial Planning Documents of the Republic of Lithuania. It registers the approved territorial planning documents.

RVIS (risk management information system) is the internal system of the Inspectorate, which identifies, assesses and manages the risks of activities of the Inspectorate, which are related to state supervision of territorial planning and construction (Nalivaikiene, 2015).

As a result of these improvements, the Doing Business index in category "Dealing with construction permits" has improved $\left(39^{\text {th }}\right.$ position in 2014 and $15^{\text {th }}$ position in 2015) (World Bank Group, 2014, 2015). The simplification measures introduced by the governmental authorities in the construction permit framework contributed to the improvement of the related index ranking. One of the reasons for the improvement is the achievement of digitalization target, by means of implementation of the above-mentioned electronical systems (OECD, 2015, pp. 168-169, p. 173).

\section{CONCLUSION}

This paper gives the overview of the commercial property market indicators in Lithuania as well as factors, which are positively influencing the commercial property development in Lithuania. In the authors' opinion, there is huge potential in Lithuania for commercial property development. Market indicators show the extension of investment volumes, rise of the rent rates.

Nevertheless, other competitive projects under development allow the developer to have a vision about potential lessee or purchaser of the premises. 
"Build-to-suit" projects are strongly recommended, when the projects are being developed according to the requirements of the end-user.

Due to governmental support and governmental activities, Lithuania is a leading country in the Baltic States in attracting international companies. Being supported by the agency "Invest Lithuania", and having tax deductions in free economic zones, these companies open shared service centres, offices, branches and factories in Lithuania. These companies need commercial premises. That gives opportunity for the developers to cooperate with international companies and to supply suitable premises.

The improvement of the construction procedures is also a positive tendency. All procedures, which are related to construction process and territorial planning, can be performed in electronical and timesaving way (online, at any day, at any time). The results of the research and data analysis can be useful for the developers, who are entering the Lithuanian commercial property market. Therefore, the good investment climate and effective construction procedures ensure favourable commercial property development activities in Lithuania.

\section{REFERENCES}

Alhammadi, Y., Algahtany, M., Kashiwagi, D., Sullivan, K., \& Kashiwagi, J. (2016). The Current State of Research and Development Approach (R\&D) in the Saudi Construction Industry. Procedia Engineering, 145, 1462-1469. http://dx.doi.org/10.1016/j.proeng.2016.04.184

BiznesPolska. (2016). 4th annual CEE Shared Services and Outsourcing Awards Gala and Summit. Winners. Retrieved from http://ceeoutsourcingawards.com/2016/winners.html

CBRE. (2015). Market review. Baltics Investment (March 2015). Retrieved from CBRE website: http://www.cbre.lv/lv_en/research

Colliers International. (2015). Real Estate Market Overview. Annual Report. Latvia. Lithuania. Estonia. Retrieved from http://www.colliers.com/lv-lv/latvia/insights/research-the-market

Colliers International. (2016). Real Estate Market Overview. Annual Review. Latvia. Lithuania. Estonia. Retrieved from http://www.colliers.com//media/files/emea/latvia/research/2016/real_estate_market_overview_2016_for_web_final.pdf

Brett, L. D., \& Schmitz, A. (2005). Real estate market analysis. Methods and Case Studies, Second Edition. USA, Washington DC: Urban Land Institute.

Giang, T. H. D., \& Pheng S. L. (2011). Role of construction in economic development: Review of key concepts in the past 40 years. Habitat International, 35, 118-125. http://dx.doi.org/10.1016/j.habitatint.2010.06.003

Invest Lithuania. (2014). Our competence to Your business. Retrieved from http://www.investlithuania.com/wp-content/uploads/2014/03/Nemunas-Valley_Lithuania.pdf

Invest Lithuania. (2016a). Our services. Retrieved from http://www.investlithuania.com/infostop/our-services/

Invest Lithuania. (2016b). Invest Lithuania breaks all records with dramatic jump in investment in 2015. Retrieved from http://www.investlithuania.com/news/invest-lithuania-breaks-allrecords-with-dramatic-jump-in-investment-in-2015/

Invest Lithuania. (2016c). Stories to share. Retrieved from http://www.investlithuania.com/storiesto-share/

Invest Lithuania. (2016d). Vilnius leading the Baltic region for investor attraction. Retrieved from http://www.investlithuania.com/news/vilnius-leading-the-baltic-region-for-investor-attraction/

Invest Lithuania. (2016e). Special economic zones. Retrieved from http://www.investlithuania.com/business-locations-projects/\#zones

Jowsey, E. (2015). Real estate concepts. A handbook. Canada: Routledge.

Maznah Mat Isa C., Mohd Saman H., \& Rahidad Mohd Nasir S. (2014). Specific-factors influencing market selection decision by Malaysian construction firms into international market. Procedia - Social and Behavioral Sciences, 129, 4-10. http://dx.doi.org/10.1016/j.sbspro.2014.03.641

Nalivaikiene, L. (2015). The performance of state territorial planning and construction inspectorate under the Ministry of environment of the Republic of Lithuania (November 27, 2015). Retrieved from 
http://kvalitatebuvnieciba.lv/wp-content/uploads/sites/14/2015/11/Current-Issues-inConstruction-in-Lithuania_Laura_Nalivaikiene27nov2015.pdf

Newsec. (2015). Baltic property Market report 2015. Retrevied from http://www.newsec.lv/parskati_newsec/baltic-property-market-report-2015-2/

OECD. (2015). Regulatory Policy in Lithuania. Focusing on the Delivery Side. Paris: OECD Publishing. http://dx.doi.org/10.1787/9789264239340-en

Thermo Fisher Scientific. (2012). Thermo Fisher Scientific Opens Molecular Biology Center of Excellence in Lithuania. Retrieved from http://news.thermofisher.com/pressrelease/corporate/thermo-fisher-scientific-opens-molecular-biology-center-excellencelithuania

Toivonen, S., \& Viitanen, K. (2015). Forces of change shaping the future commercial real estate market in the Helsinki Metropolitan Area in Finland. Land Use Policy, 42, 471-478. http://dx.doi.org/10.1016/j.landusepol.2014.09.004

Toivonen, S., \& Viitanen, K. (2016). Environmental scanning and futures wheels as tools to analyze the possible future themes of the commercial real estate market. Land Use Policy, 52, 51-61. http://dx.doi.org/10.1016/j.landusepol.2015.12.011

Vastint. (2015). IT Unit of Danske Bank to set up in UNIQ Business Centre. Retrieved from $\mathrm{http} / / /$ vastint.eu/lt/record-breaking-transaction-it-unit-of-danske-bank-to-set-up-in-uniqbusiness-centre/

Wofford, E. L., \& Clauretie, M. T. (1992). Real Estate. (3rd ed.). Canada: John Wiley \& Sons Inc.

World Bank Group. (2014). Doing Business 2014. Understanding regulations for Small and Medium-Size Enterprises. Retrieved from http://www.doingbusiness.org/ /media/GIAWB/Doing\%20Business/Documents/AnnualReports/English/DB14-Full-Report.pdf

World Bank Group. (2015). Doing Business 2015. Going Beyond Efficiency. Retrieved from http://www.doingbusiness.org/ /media/GIAWB/Doing\%20Business/Documents/AnnualReports/English/DB15-Full-Report.pdf

World Economic Forum. (2016). Competitiveness Rankings 2015-2016. Retrieved from http://reports.weforum.org/global-competitiveness-report-2015-2016/competitivenessrankings/

\section{AUTHORS' SHORT BIOGRAPHIES}

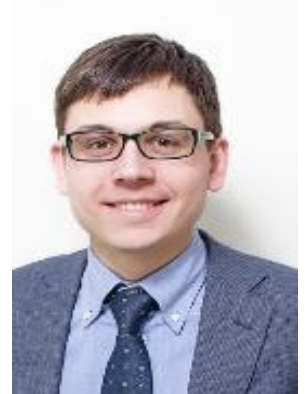

Valery Komisarov, Mg. iur., Mg. oec., he with distinction obtained Professional Master Degree in Civil Construction and Real Estate Management from Riga Technical University, has the qualification of Real Estate Economist. He is an owner of the real estate company "KOMINVEST" and legal office "VK legal". He has extensive practical experience in providing legal support on real estate transactions and on property development projects. He has experience in cooperation with foreign investors. His main research areas are real estate market and macroeconomic analysis, business cycle, decision-making, property and construction rights, property development. He is FIABCI Young member.

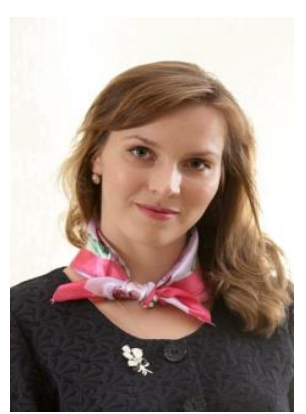

Linda Kauškale, $\mathrm{Mg}$. oec., is a lecturer, a PhD student and an assistant researcher with the Institute of Civil Engineering and Real Estate Economics, Faculty of Engineering Economics and Management, Riga Technical University. She with distinction obtained Professional Master Degree in Civil Construction and Real Estate Management, has the qualification of Real Estate Economist and extensive practical experience. She has participated in international scientific conferences in United Arab Emirates, Malaysia, Singapore, Lithuania, etc. Her main research areas are real estate market and macroeconomic analysis, business cycle, sustainable construction, decision making, environmental development, etc. She is a Professional Member of Industrial Engineering and Operations Management Society. In autumn 2013, she was a FIABCI scholar.

ORCID iD: http://orcid.org/0000-0002-0280-2977 


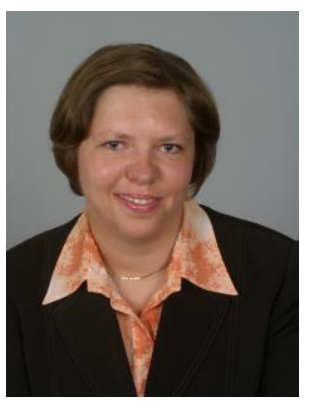

Natalija Lepkova is a Doctor of Technological Sciences. She is an Associate Professor with the Department of Construction Economics and Property Management, Faculty of Civil Engineering, Vilnius Gediminas Technical University.

Her main research areas are facilities management, real estate management, quality management systems, distance learning.

She has participated in such international projects as INTEREG Project Longlife, COST Project, etc. She is author and co-author of several textbooks on facilities management and sustainable development, as well as of articles published in various national and international publications.

She is a member of editorial board of the following journals: International Women Online Journal of Distance Education, Turkish Online Journal of Distance Education, GLOKALde - an official ejournal of UDEEEWANA-United Distance Education for Eastern Europe, Western Asia, Northern Africa. 